\title{
FUNGI COLONIZING DEAD LEAVES OF HERBS
}

\author{
Maria Kowalik \\ Department of Plant Protection, Faculty of Horticulture, University of Agriculture in Krakow \\ al. 29 Listopada 54, 31-425 Kraków, Poland \\ e-mail:m.kowalik@ogr.ur.krakow.pl
}

Received: 16.10 .2012

\begin{abstract}
The material was collected from the Botanical Garden and the Collegium Medicum Medicinal Plant Garden of the Jagiellonian University in Krakow. The investigated species were: lemon balm (Mellisa officinalis L.), common lavender (Lavendula angustifolia Mill.), horsemint (Mentha longifolia L.), sage (Salvia officinalis L.), sweet basil (Ocimum basilicum L.), and wild marjoram (Origanum vulgare L.). The aim of the investigation was to identify fungi causing the death of leaf tissues of herbs from the mint family Lamiaceae. In mycological investigations, 180 fragments of each plant leaves (1,080 dead leaf fragments in total) were placed in a $2 \%$ PDA medium. Over 970 colonies of fungi belonging to 48 species were isolated from the dead leaf tissues of the six herb species. Alternaria alternata (toxin-producing), Epicoccum nigrum and Sordaria fimicola were the most frequently isolated. The largest numbers of colonies and species of fungi were isolated from horsemint, while the lowest numbers were from wild marjoram leaves. It was shown that the death of leaves of selected herb species from the Lamiaceae family was caused by various fungi. The results of the mycological analysis confirmed the diversity of species colonizing the leaves of the herbs.
\end{abstract}

Key words: Lamiaceae, herbs, leaves, fungi, necroses

\section{INTRODUCTION}

Herbs, like all plants, are susceptible to infectious disease pathogens. Disease symptoms manifested as necrotic tissue are common in herbal plants, despite the anti-fungal properties of active substances derived from this group of plants ( $\mathrm{Garibaldi}$ et al. 1997; Machowicz-Stefaniak et al. 2003). Infection can lead to the reduction in the decorative qualities of plants, significant crop loss, and the deterioration of medicinal raw materials. The pathogens most commonly found on herbs are fungi and fungi-like Chromista organisms (M a c h o w i c z-S te f a niak et al. 2003;
Zalewska and Machowicz-Stefaniak, 2004; Łabanowski et al. 2005; Adamska, 2006; Kołodziej, 2010; Zi mows ka, 2010).

The aim of this study was to investigate the microorganisms that colonize dead leaves of herbs.

\section{MATERIALS AND METHODS}

The research material was collected from the Botanical Garden of the Jagiellonian University and the Medicinal Plants Garden of the Jagiellonian University in Krakow, from May to September 2011 and 2012. The study was conducted on: lemon balm (Mellisa officinalis L.), common lavender (Lavendula angustifolia Mill.) horsemint (Mentha longifolia L.), sage (Salvia officinalis L.), sweet basil (Ocimum basilicum L.), and wild marjoram (Origanum vulgare L.). In mycological investigations, 180 fragments of herb leaves, taken from the edges of living and dead tissue, were placed in a 2\% PDA medium. The taxonomic identification of isolated species of fungi was determined using the classifications by B o oth (1971), Ell is and E 11 is (1985) as well as D o m s ch et al. (1980). The system by $\mathrm{K}$ ir k et al. (2008) for determinate verification in naming fungi according to the Index Fungorum (2012) was used as the basis of classification.

\section{RESULTS AND DISCUSSION}

Brownish or brown necrotic spots were visible on the blades and petioles of the tested herb species, sometimes with a narrow lighter border. With time, the leaf tissue dried out and disintegrated.

The mycological analysis of dead tissue covering large areas of leaves showed that these symptoms were caused by fungi from the kingdom Fungi, belonging to 48 species. Over 970 colonies of fungi were isolated from the infected tissue. Most of colonies and 
species of fungi were isolated from horsemint (205 and 27) and fewest of all from wild marjoram (117 and 10). A comparable number of species of fungi (21-22) were isolated from lemon balm, lavender, sage and basil, with varying numbers of colonies (135-189).

The most frequently isolated fungi were: Alternaria alternata (33.02\%), Epicoccum nigrum (12.55\%), and Sordaria fimicola (representing 5.86\% of the total isolated colonies). Fungi belonging to the genera Chaetomium, Cladosporium, Humicola, Mortierella, Penicillium and Umbellopsis were isolated from leaves of most of the herb species (Table 1).

The toxin-producing species A. alternata was found on all tested herbs, causing the symptoms of alternaria blight on leaves. For basil leaves, this fungus amounted to over $50 \%$ of isolates. An equally high proportion of the pathogen was found in the fungal communities isolated from the leaves of wild marjoram, lavender and sage, in which isolates from communities of A. alternata made up over 42,38 and $30 \%$ of isolated fungi, respectively. An even higher proportion of A. alternata (over $76 \%$ ) was reported by Machowicz-Stefaniak and $\mathrm{Zalewska}$ (2007) on dying dill plants. The necrotrophs E. nigrum and S. fimicola also occurred frequently on all studied herb species, though their percentage in all communities was lower and more variable. $E$. $n i$ grum ranged from $7 \%$ (in fungal colonies isolated from horsemint leaves) to $24 \%$ (from lemon balm leaves). The occurrence of S. fimicola was highest among fungi colonies isolated from leaves of wild marjoram (over 18\%) and lowest among fungi found on lavender, horsemint and basil (1-2\%). Fungi of the genera Fusarium and Giberella also occurred on dead herb leaves, including F. chlamydosporum var. chlamydosporum on horsemint. The species Mortierella and Umbellopsis (syn. Mortierella) were found on the leaves of all herbs, with the exception of wild marjoram, accounting for over $7 \%$ of all isolated colonies. These fungi colonize the youngest, most sensitive leaf blades under conditions of high humidity. Fungi of the species Penicillium and Aspergillus did not colonize dead marjoram leaves, either, but were occasionally found inhabiting other herbs. Fungi of the genera Phoma and Boeremia were found on common lavender, horsemint and sage. The study also detected a small share of fungi from the genus Cladosporium, which has been confirmed by Machowicz-Stefaniak et al. (2003), Machowicz-Stefaniak and Zalewska (2007) as well as Zimowska (2010). Single Thanatephorus cucumeris colonies were isolated from horsemint, although in the study by $\mathrm{Zi}$ m o w s k a (2010) the pathogen appeared with a frequency of up to $15 \%$ on peppermint and sage. The fungus Trichoderma viride, noted in many studies on herbal crop health, was not found on dead lavender and lemon balm leaves. Septoria melissae, which affects Melissa, was occasionally found on the oldest leaves (Table 1).
The incidence of A. alternata was particularly dangerous on basil leaves, because it led to premature drying and loss of leaves and to a lower quality of raw material, which has been confirmed by $\mathrm{Mach}$ owic z-S te faniak et al. (2003) as well as Mazur and $S \mathrm{z}$ c ze p o n e k (2006). The herbal literature also highlights the extensive damage caused by $B$. cinerea and E. nigrum to basil (G a ri b a ld i et al. 1997; Mazur and Szczeponek, 2006). Machowicz-Stefaniak et al. (2002), Zalewska and Machowicz-Stefaniak (2004), Mazur and S zczeponek (2006), Fruży ńska- Jóźwiak and Andrzejak (2007) reported the risk of disease caused by Fusarium spp. for herbs. In the present study, only a few colonies of Fusarium spp. were isolated from dead leaves of mint and lavender, and its presence was not confirmed on the leaves of basil, marjoram or sage, while Fruży ńska-Jóźwiak and Andrzejak (2007) reported that lemon balm plants were often colonized by $F$. avenaceum, $F$. oxysporum, $B$. cinerea and $S$. melissae, peppermint plants by $F$. avenaceum and $F$. oxysporum, and sage by $F$. culmorum, $F$. oxysporum and T. cucumeris.

Sage leaves were mostly colonized by A. alternata, E. nigrum, Humicola grisea var. grisea, Ilionectria radicicola, Phoma medicaginis and S. fimicola. A comparison of the results to those of $\mathrm{Zi} \mathrm{m} \mathrm{ow} \mathrm{s} \mathrm{k} \mathrm{a}$ (2010) found that the occurrence of the first two species were similar to that on sage plants in plantations and in the collections of the Botanical Garden and the Garden of Medicinal Plants of the Jagiellonian University. The study by $\mathrm{Zi} \mathrm{mow}$ s k a (2010) also confirmed the significant role of A. alternata, B. cinerea, E. nigrum and Fusarium and Trichoderma fungi in the death of mint leaves.

According to Chełkowski (2012), tissue decay occurs due to the effects of enzymes, or toxins, as well as the effects of necrogenic substances. Mycotoxins produced by Aspergillus and Penicillium inhibit the metabolism of plants and are also produced by pathogens of the genera Alternaria, Phoma and Fusarium, which are characterised by strong phytotoxicity, causing symptoms of necrosis and leaf drop. It can be assumed that $A$. alternata mycotoxins, or alternariol and tenuazonic acid, played a significant role in causing leaf necrosis in the investigated herb species. Ch e $1-$ k ow s k i (2012) determined that toxin-producing fungi are generally accompanied by various fungi that are not toxin-producing. This is evidenced by the relatively large number of different species of fungi inhabiting the herb phyllosphere and damaging their leaves.

The present study showed that on the test material, which consisted of selected species of herbs from the Lamiaceae family, leaf death was caused by a complex of fungi and mycological analysis confirmed the diversity of fungi colonizing them. 
Table 1

Fungi isolated from dead leaves of herbs

\begin{tabular}{|c|c|c|c|c|c|c|c|c|}
\hline Fungus & 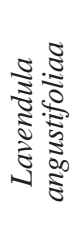 & 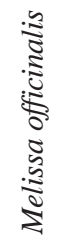 & 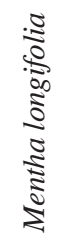 & 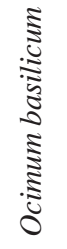 & 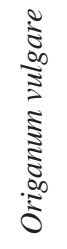 & 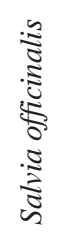 & 胥 & 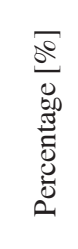 \\
\hline Alternaria alternata (Fr.) Keissl. & 60 & 25 & 38 & 96 & 50 & 52 & 321 & 33.02 \\
\hline Arthrinium phaeospermum (Corda) M.B. Ellis & & & 1 & & & & 1 & 0.10 \\
\hline Aspergillus brasiliensis Varga, Frisvard \& Samson & & & 2 & & & & 2 & 0.21 \\
\hline Aspergillus versicolor (Vuill.) Tirab & & & 1 & & & & 1 & 0.10 \\
\hline Aureobasidium pullulans (de Bary) G. Arnaud & & & & 1 & & & 1 & 0.10 \\
\hline Boeremia exigua (Desm.) Aveskamp, Gruyter \& Verkley var. exigua & & & 12 & & & & 12 & 1.23 \\
\hline Botrytis cinerea Pers. & & & 11 & 5 & 1 & & 17 & 1.75 \\
\hline Chaetomium globosum Kunze & & 1 & 11 & 2 & 1 & & 15 & 1.54 \\
\hline Chetomium nozdrrenkoae Sergeeva & & & & & & 5 & 5 & 0.51 \\
\hline Cladosporium cladosporioides (Fresen.) G.A. de Vries & 11 & 3 & 2 & & & 1 & 17 & 1.75 \\
\hline Cladosporium herbarum (Pers.) Link & & & & & 11 & 1 & 12 & 1.23 \\
\hline Cladosporium sphaerospermum Penz & & 2 & 9 & 1 & & & 12 & 1.23 \\
\hline Davidiella macrocarpa Crous, K. Schub. \& U. Braun & & 2 & & & 6 & & 8 & 0.82 \\
\hline Epicoccum nigrum Link & 19 & 33 & 15 & 17 & 12 & 26 & 122 & 12.55 \\
\hline Fusarium chlamydosporum var. chlamydosporum Wollenw. \& Reinking & & 1 & 5 & & & & 6 & 0.62 \\
\hline Fusarium oxysporum E.F. Sm. \& Swingle & 1 & & & & & & 1 & 0.10 \\
\hline Giberella baccata (Wallr.) Sacc. & & & & & & 1 & 1 & 0.10 \\
\hline Giberella stilboides W.L. Gordon ex C. Booth & 6 & & & & & & 6 & 0.62 \\
\hline Humicola fuscoatra var. fuscoatra Traaen & & & & 7 & 5 & 1 & 13 & 1.34 \\
\hline Humicola grisea var. grisea Traaen & 1 & 7 & & 5 & & 14 & 27 & 2.78 \\
\hline Ilyonectria radicicola (Gerlach \& L. Nilsson) Chaverri \& C. G. Salgado & 8 & 5 & 2 & & & 11 & 26 & 2.67 \\
\hline Isaria farinosa (Homsk.) Fr. & & & & 2 & & & 2 & 0.21 \\
\hline Khuskia oryzae H.J. Huds. & & & & 1 & & 1 & 2 & 0.21 \\
\hline Mammaria echinobotryoides Ces. & & 1 & & 1 & & & 2 & 0.21 \\
\hline Mortierella alpina Peyronel & 1 & 1 & 2 & & & & 4 & 0.41 \\
\hline Mortierella horticola Linnem. & 6 & & & & & & 6 & 0.62 \\
\hline Mortierella parvispora Linnem. & & & 1 & 1 & & 1 & 3 & 0.31 \\
\hline Mucor hiemalis var. hiemalis Wehmer & 3 & 5 & 10 & 7 & & & 25 & 2.57 \\
\hline Penicillium expansum Link & 2 & & 11 & 4 & & 1 & 18 & 1.85 \\
\hline Penicillium glabrum (Wehmer) Westling & & & & & 2 & 1 & 3 & 0.31 \\
\hline Penicillium hirsutum Dierckx var. hirsutum & & 4 & 3 & 2 & & & 9 & 0.93 \\
\hline Penicillium verrucosum var. verrucosum Dierckx & 3 & 5 & 2 & 4 & & 2 & 16 & 1.65 \\
\hline Phoma eupyrena Sacc. & & & & & & 5 & 5 & 0.51 \\
\hline Phoma herbarum Westend & 1 & 4 & & & & 7 & 12 & 1.23 \\
\hline Phoma medicaginis Malbr. \& Roum. & 13 & & & & & 12 & 25 & 2.57 \\
\hline Preusia aemulans (Rehm) Arx & 1 & & & & & & 1 & 0.10 \\
\hline Rhizopus stolonifer (Ehrenb.) Vuill. & 3 & & & 3 & & & 6 & 0.62 \\
\hline Septoria mellissae Desm. & & 5 & & & & & 5 & 0.51 \\
\hline Sordaria fimicola (Roberge ex Desm.) Ces. \& De Not & 2 & 16 & 4 & 4 & 22 & 9 & 57 & 5.86 \\
\hline Stemphylium botryosum Sacc. & 9 & 4 & 2 & & & & 15 & 1.54 \\
\hline Talaromyces wortmannii C.R. Benj. & & & & & & 5 & 5 & 0.51 \\
\hline Thanatephorus cucumeris (A.B. Frank) Donk & & & 2 & & & & 2 & 0.21 \\
\hline Trichoderma viride Pers. & & & 10 & 12 & 7 & 6 & 35 & 3.60 \\
\hline Truncatella truncata (Lév.) Steyaert & 1 & 3 & 26 & & & & 30 & 3.09 \\
\hline Umbellopsis ramaniana (Möller) W. Gams & 1 & 3 & 7 & 2 & & & 13 & 1.34 \\
\hline Umbellopsis vinacea (Dixon-Stew.) Arx & & & 4 & & & & 4 & 0.41 \\
\hline Umbelopsis isabellina (Oudem) W. Gams & 4 & 5 & 10 & 11 & & 5 & 35 & 3.60 \\
\hline Umbelopsis nana (Linnem.) Arx & 1 & & 2 & 1 & & 2 & 6 & 0.62 \\
\hline Total & 157 & 135 & 205 & 189 & 117 & 169 & 972 & 100.0 \\
\hline
\end{tabular}




\section{CONCLUSIONS}

1. Leaf death in lemon balm, lavender, horsemint, sage, common basil and wild marjoram was caused by numerous fungi found on the leaves, representing a variety of species.

2. Alternaria alternata, Epicoccum nigrum and Sordaria fimicola were considered to be particularly dangerous, as evidenced by widespread colonization on herb leaves.

3. The presence of toxin-producing A. alternata species on the herb phyllosphere often indicated the intensity of leaf damage.

4. Assessing the health of herbs growing in the same soil and climatic conditions, it was found that fungi prefer the environment of horsemint and basil plants.

\section{Acknowledgements}

Research supported by the Ministry of Science and Higher Education of Poland as the part of statutory activities of Department of Plant Protection, University of Agriculture in Krakow.

\section{REFERENCES}

Adamska I. 2006. Choroby grzybowe ziół i ich sprawcy. Progress in Plant Protection / Postępy w Ochronie Roślin, 46 (2): 654-656. (in Polish)

B o oth C. 1971. The Genus Fusarium. Commonwealth Mycological Institute, Kew, Surrey, England. http://dx.doi. org/10.2307/1219251

Chełkowski J.2012. Mikotoksyny, grzyby toksynotwórcze i mikotoksykozy. On line www.cropnet.pl/mycotoxin, dostęp 2.10.2012. (in Polish)

Domsch K.H., Gams W., Anderson T.H. 1980. Compendium of Soil Fungi. Academic Press, London, New York, Toronto, Sydney, San Francisco.

Garibaldi A., Gullino L.M., Minuto G. 1997. Diseases of basil and their management. Plant Dis. 81(2): 124-131. http://dx.doi.org/10.1094/PDIS.1997.81.2.124

E11 is M.B, E11 is J.P. 1985. Microfungi on Land Plants. Croom Helm London, Sydney.

Frużyńska-Jóźwiak D., Andrzejak R. 2007. The incidence of diseases and pathogenic fungi on selected medicinal and spice plants in the area of Poznań. Phytopathol. Pol. 46: 47-51.

Index Fungorum. On line www.indexfungorum.org.names/Names.asp, dostęp 2.10. 2012.

Kirk P.M., Cann on P.F., Minter D.W., Stalpers J.A. 2008. Ainswort \& Bisby's Dictionary of the Fungi. CAB International, Wallingford, UK.

Kołodziej B. (red). 2010. Poradnik dla plantatora ziół, uprawa ziół. PWRiL, Poznań. (in Polish)

Łabanowski G., Orlikowski L., Skrzypczak C., Soika G., Wojdyła A. 2005. Ochrona bylin. Plantpress. (in Polish)
Machowicz-Stefaniak Z., Gabler J., Zalewska E. 2003. Patogeny zagrażające uprawie roślin zielarskich / Pathogens threaten the cultivation of herb plants. Folia Horticulturae, suplement 2003/1: 565-567. (in Polish)

Machowicz-Stefaniak Z., Zalewska E., Zimowska B. 2002. Fungi colonizing various organs of lemon balm (Mellisa officinalis L.) cultivated in South-East Poland. Proc. $6^{\text {th }}$ Conf. EFPP 2002, Praguae. Plant Protect. Sci. 38: 353-356.

Machowicz-Stefaniak Z., Zalewska E. 2007. Bioróżnorodność grzybów występujących na nadziemnych organach kopru ogrodowego (Anethum graveolens L.) / Biodiversity of fungi occurring on above-ground parts of dill (Anethum graveolens L.). Progress in Plant Protection / Postępy w Ochronie Roślin, 47 (2): 182-185. (in Polish)

Mazur S., Szczeponek A. 2006. Zdrowotność bazylii (Ocimum basilicum L.) uprawianej w warunkach polowych / Healthiness of sweet basil (Ocimum basilicium L.) grown in field conditions. Folia Horticulturae, suplement 2: 16-20. (in Polish)

Zalewska E., Machowicz-Stefaniak Z. 2004. Patogeniczność grzybów z rodzaju Fusarium dla melisy lekarskiej / Pathogenicity of Fusarium spp. to lemon balm (Mellisa officinalis L.). Acta Sci. Pol. Hortorum Cultus, 3(2): 33-39. (in Polish)

Zimowska B. 2010. Diversity of fungi occurring on herbs from the Lamiaceae family. Phytopathol. 56: 5-15.

\section{Grzyby zasiedlające obumarłe liście ziół}

\section{Streszczenie}

Materiał badawczy pobrano w Ogrodzie Botanicznym UJ i w Ogrodzie Roślin Leczniczych Collegium Medicum UJ. Badania prowadzono na: bazylii pospolitej (Ocimum basilicum L.), lawendzie wąskolistnej (Lavendula angustifolia Mill.), lebiodce pospolitej (Origanum vulgare L.), melisie lekarskiej (Mellisa officinalis L.), mięcie długolistnej (Mentha longifolia L.) i szałwii lekarskiej (Salvia officinalis L.). Celem pracy było poznanie grzybów zasiedlających obumarłe liście ziół z rodziny jasnotowatych Lamiaceae. W badaniach mykologicznych wyłożono na $2 \%$ pożywkę PDA po 180 fragmentów liści ziół, w sumie 1080 obumarłych fragmentów liści. Z martwych tkanek liści sześciu gatunków ziół wyodrębniono ponad 970 kolonii grzybów, należących do 48 gatunków. Najczęściej izolowanymi grzybami z porażonych liści były: Alternaria alternata (toksynotwórczy), Epicoccum nigrum i Sordaria fimicola. Najwięcej kolonii i gatunków grzybów wyizolowano z mięty długolistnej, a najmniej z lebiodki pospolitej. Wykazano, że na materiale badawczym, jakim były wybrane gatunki ziół z rodziny Lamiaceae, obumieranie liści powodował najczęściej kompleks grzybów, a wyniki analizy mykologicznej potwierdziły różnorodność grzybów je zasiedlających. 